\title{
Modeling of Three Flat Coal Seams Strata Developing at Open Pit Miming
}

\author{
Tatiana Gvozdkova ${ }^{1, *}$, Sergey Markov ${ }^{1,2}$, Nuray Demirel $^{3}$, and Serony Anyona ${ }^{4}$ \\ ${ }^{1}$ Kuzbass State Technical University, Mezhdurechensk branch, Mezhdurechensk, 652881, Stroitelei \\ Avenue, 36, Russia \\ ${ }^{2}$ T.F. Gorbachev Kuzbass State Technical University, 650000, 28 Vesennyaya St., Kemerovo, Russia \\ ${ }^{3}$ Mining Engineering Department, Middle East Technical University, Üniversiteler Mah., \\ Dumlupınar Bulvarı, No: 1, 06800 Çankaya, Ankara, Turkey \\ ${ }^{4}$ Jomo Kenyatta University of Agriculture \& Technology, Mining, Materials \& Petroleum \\ Engineering Department, P.O. Box 62000 - 00200, Nairobi, Kenya
}

\begin{abstract}
The use of low-cost direct dumpling technology, as is well known, has a relatively limited field of application: flat coal seams, and the higher the dip angle of the seam, the more difficult it is to place the necessary volume of overburden rock in the dumping layers. For this, we have to pour four-tier dumps. In this article, four possible options for piling the dump have been studied and prerequisites have been made for further research aimed at improving the efficiency of the use of direct dumpling technology in the development of flat coal seams.
\end{abstract}

\section{Introduction}

At present time economic development of Kuzbass coal industry is the key to the neoindustrial transformation of such mineral resources extracting region. Development of coal mining must accelerate making deep processing of coal and raise the common technological level of regional industry [1-4]. For Kuzbass, the biggest Russian coal basin (located Western Siberia) development of coal mining means expansion of open pit mining.

However when open pit mines increase in numbers it means growth of the area of land occupied by quarry fields, additional load on environment, mainly on air and water sources. This can be reduced by backfilling internal dumps with the change of surface mining technology from transport to direct dumping. The increase in the volume of the rock, moved into the internal dump, will improve the economic indicators of open pit coal mining [5-8]. In addition, because of the flat bedding of the coal seams of open pits of South Kuzbass (Western Siberia, Russia), the height of the rock mass, which is processed by transport technology, is constantly increasing [9-10]. At present, this has led to a decrease in the speed of moving the front of mining work of the transport zone and, as a result, to the inhibition of the development of the transportless [11]. The redistribution of volumes of overburden between zones in the direction of increasing the volume of direct dumpling technol-

\footnotetext{
*Corresponding author: kuzstu@kuzstu.su
} 
ogy will increase the speed of movement of the transport zone (while maintaining the same complex of mining and transport equipment).

Thus, the increase in the volume of the rock moved into the internal dump in these deposits contributes to the improvement of the seam development indices, and the solution of this issue is an actual task. Also the transport technology change to direct dumping can contribute to the improvement of environmental problems caused by surface mining like air and water pollution [12-16].

A particular feature of this study is the analysis of a group of deposits that are complex in terms of mining and geological conditions and are systematized in terms of $\tau$, instead of observing a separate deposit, represented by strata of three flat coal seams. Consequently, the solution of the task based on the justification of the structure of the excavation schemes is not for any separate strata, but for a group of stratas, which implies the multivariance of the solution.

Such research object requires an appropriate methodological approach to the solution of the task.

\section{Materials and Methods}

The main direction to increase the competitiveness of Kuzbass coals produced by the open pit miming is to reduce overburden costs. On the open pits of Southern Kuzbass, the stratas of flat coal seams are developing with direct dumpling technology for overburden mining.

At present, in scientific research, modeling is used with sufficient confidence to predict the parameters of technological processes.

As is known from theory, modeling is the replacement of the study of an object under observation in nature by a similar study of it on a model. In turn, the model is a system of thoughts fixed on paper in the form of drawings, graphs, formulas, equations, etc., and is characterized by the fact that the unity and integrity of each such system is due to the relationship of properties and interrelations in the object under study.

Any model has some ideal content. At the same time, the spatial properties of the object, the interaction and interconnection of parts, etc. should be transferred to the model. Models can be ideal, not completely reflecting reality, and material - in the form of machines, mechanisms, etc.

Proceeding from these methodological provisions, an ideal grapho-analytical model for the development of a series of three flat coal seams is proposed to solve the scientific task.

\section{Results and Discussion}

The initial position of the model consists of two elements: the face and the dump sides (Figure 1).

In Fig. 1 the following legend is accepted: $A$ - the width of the excavator (dragline) stope, $\mathrm{m} ; R$-digging radius, $\mathrm{m} ; R_{p}$ - downloading radius, $\mathrm{m}$.

The face side of the model includes options for developing a strata of three flat coal seams. The idealization of this element of the model is as follows. The first (lower) and third (upper) seams are stationary; the distance between them (from the soil of the upper seam to the roof of the lower one) is constant and equals to $52 \mathrm{~m}$, which is accepted according to the statistical analysis of bedding of the considered stratas [17]. The middle seam has a variable position, which is fixed by the value of the exponent $\boldsymbol{\tau}$ at a given thickness or lower interbed $\left(H_{1}\right)$, or upper $\left(H_{2}\right)$. The height of the bench marking $\left(H_{3}\right)$ is set in the range from $10 \mathrm{~m}$ to $H_{c . \max }$, where $H_{c . \max }$ is determined by the formula, m:

$$
H_{c . \max }=H_{s 4}-H_{1}-H_{2}
$$


where: $H_{s 4}$ - total height of the developed rock mass, determined by the maximum capacity of the dump, $\mathrm{m}$.

The coal seams' thickness $m_{i}\left(m_{1}, m_{2}, m_{3}\right)$ and their dip angle $(\varphi)$ are determined from the results of a statistical analysis of the six stratas [18] and are calculated by the formula (2):

$$
m_{i}=\frac{1}{6} \cdot \sum_{n=1}^{n=6} \bar{m}_{i . n}
$$

where: the sequence number of the formation from the bottom up $(\mathrm{i}=1 ; 2 ; 3) ; \mathrm{n}$ - serial number of the suite according to the developed systematization;

$\overline{\mathrm{m}}_{\mathrm{i} . \mathrm{n}}$ - the average value of the thickness of the i-th seam, obtained during a statistical analysis of bedding parameters, $\mathrm{m}$;

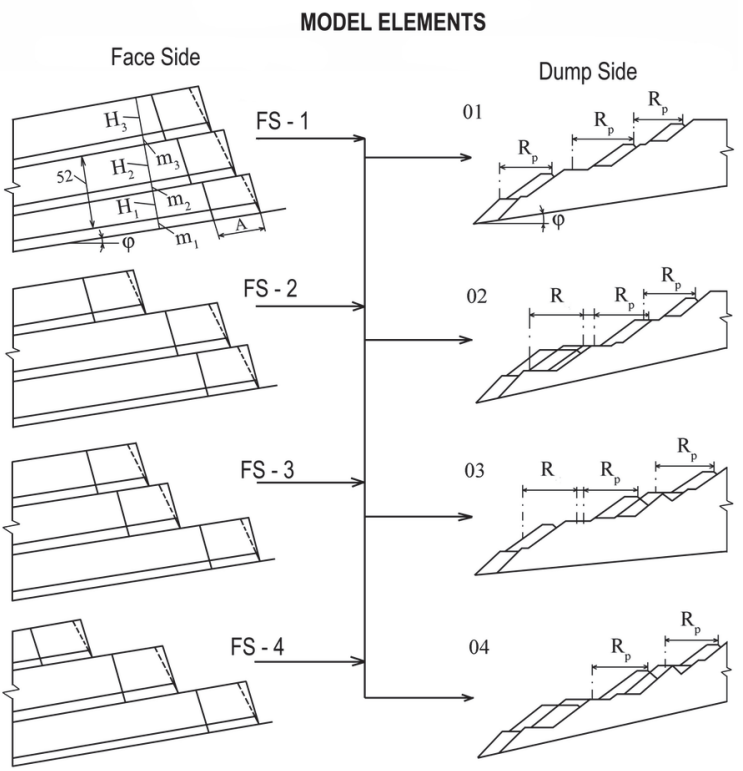

Fig. 1. Structure of the grapho-analytical model for the development of three flat coal seams strata, taking into account the different dumping schemes.

The average angles of bedding are in the range of $6^{0}-10^{\circ}$, so the modeling of development of the flat coal seamsof strata is made within these limits.

The dump side of the model includes four schemes of dumping, according to their systematization. The idealization of this part of the model is as follows. The full use of the working parameters of the draglines during the backfilling the dump's tiers is accepted, and the images of the elements of the dump and the dumping tiers are taken by regular polygons.

The proposed structure of the graph-analytical model is subject to the requirement of a methodical approach to solving mining problems of open pit mining for the movement of rock masses in the space.

In this study, the solution to the problem of developing the structures of excavation schemes is connected with the analysis of transshipment of the rock mass by a dragline excavator from three overburden benches to dumping tiers. Such problems belong to the class of problems of dynamic geometry and are solved by dividing the process of trans- 
shipment of the rock into separate static stages; each of them is solved by methods of classical geometry.

With this methodological approach, the face and dump sides in the proposed model are the initial and final static stage. The dynamics of moving rock between these stages will depend on the way the side is developed, the bedding parameters of the coal seams, the width of the drilling and blasting stope, the type of the dump formation scheme, the working parameters of the dragline, which will determine the structure of the excavation scheme.

One of the tasks of the excavating scheme selection is to identify typical schemes. In this regard, it is necessary to clarify the notion of a "typical excavation scheme".

The whole process of extracting the overburden rock and moving it to the inner dump is, according to the general theory of open pit mining, an excavation scheme. Schemes of excavation differ in their structure by the number of stages of development and transshipment of the overburden rock, as well as by technological interconnection between them (in different mining and geological conditions or under the same conditions) when the locations of the dragline installation are changed in the profile of the face.

If the number of stages and the technological connection between them are the same, but the geometric shape of the stages and their sizes may differ, then such excavation schemes can be defined as monotype. In the paper, based on the construction of a number of options for excavation schemes, typical schemes are used.

\section{Conclusion}

According to the proposed structure of the model, each element of the face side (the initial stage of the excavation scheme) can interface with any element of the dumping site (the final stage of the excavation scheme). In addition, by changing the position of the middle seam on the geological structure of the face side, it is possible to study the relationship between the conditions of seams' bedding in the strata and the method of its development, taking into account any of the heaping patterns.

Thus, the model allows assigning any number of variants of excavation schemes for interconnection of the main influencing factors.

\section{References}

1. Zhironkin, S.A., Ugol', 6, 62-63 (2001)

2. A.V. Myaskov, A.S. Ilyin, S.M. Popov, Gornyi Zhurnal, 2, 51-56 (2017)

3. E. Dotsenko, N. Ezdina, E3S Web of Conf., 15, 04012 (2017)

4. M.A. Gasanov, K.A. Kolotov, K.A. Demidenko, E.A. Podgornaya, O.V. Kadnikova, IOP Conf. Ser.: Earth Environ. Sci., 50:1, 012025 (2017)

5. M. Cehlár, L. Mihok, Theor. Emp. Res. Urb. Man., 8:4, 60-72 (2013)

6. Z. Jurkasová, M. Cehlár, S. Khouri, Int. Conf. on Engin. Sci. and Prod. Man., ESPM, 409-412 (2015)

7. M. Cehlár, J. Janočko, Z. Šimková, T. Pavlik, E3S Web of Conf., 15, 01019 (2017)

8. M. Cehlár, Z. Šimková, Economics and Innovation Management, 1, 52-65 (2017) DOI: 10.26730/2587-5574-2017-1-52-65

9. M. Tyulenev, S. Zhironkin, E. Tyuleneva, A. Abay, S. Anyona, M. Hellmer, Coal Int., 265:3, 30-34 (2017) 
10. S. Markov, M. Tyulenev, O. Litvin, E. Tyuleneva, E3S Web of Conf., 15, 01011 (2017)

11. M.A. Tyulenev, S.A. Zhironkin, O.I. Litvin, E.A. Tyuleneva, O.V. Zhironkina, S.O. Markov, Geotech. Geol. Eng. 35:5, 2065-2077 (2017)

12. M. Tyulenev, Y. Lesin, E. Tyuleneva, E. Murko, E3S Web of Conf., 15, 02003 (2017)

13. M. Tyulenev, E. Garina, A. Khoreshok, O. Litvin, Y. Litvin, E. Maliukhina, IOP Conf. Ser.: Earth Environ. Sci., 50:1, 012035 (2017)

14. Tyulenev, M., Zhironkin, S., Kolotov, K., Garina, E., Poll. Res. 35:2, 221-227 (2016)

15. M.I. Agienko, E.P. Bondareva, G.V. Chistyakova, O.V. Zhironkina, O.I. Kalinina, IOP Conf. Ser.: Earth Environ. Sci., 50:1, 012022

16. M.A. Tyulenev, T.N. Gvozdkova, S.A. Zhironkin, E.A. Garina, Geotech. Geol. Eng., 35:1, 203-212 (2017)

17. T. Gvozdkova, E. Kuznetsov, A. Rudakova, S. Markov, E3S Web of Conf., 15, 01008 (2017) 
